\title{
Computed tomographic and radiologic anatomy of the lower respiratory tract in the red-foot tortoise (Chelonoidis carbonaria) $^{1}$
}

\author{
Joshua Benjamín Andrés Polanco ${ }^{2}$, Maria Jaqueline Mamprim ${ }^{2,3}$, Jeana P. Silva ${ }^{2}$, \\ Letícia R. Inamassu ${ }^{2}$ and Bruno Cesar Schimming $2,4 *$ (D)
}

\begin{abstract}
Polanco J.B.A., Mamprim M.J., Silva J.P., Inamassu L.R. \& Schimming B.C. 2020. Computed tomographic and radiologic anatomy of the lower respiratory tract in the red-food tortoise (Chelonoids carbonaria). Pesquisa Veterinária Brasileira 40(8):637-646. Departamento de Anatomia, Instituto de Biociências, Universidade Estadual Paulista "Júlio de Mesquita Filho", Rua Prof. Dr. Antônio Celso Wagner Zanin 250, Distrito de Rubião Junior, Botucatu, SP 18618-689, Brazil. E-mail: bruno.schimming@unesp.br

The diagnosis of several diseases in chelonians is a challenge in the veterinary clinic, because a detailed physical examination with auscultation and palpation is difficult due the presence of carapace and plastron. Imaging analysis such as radiography and computed tomography (CT) have been shown to be beneficial for diagnosis, prognosis and treatment in numerous animal species. Thus, this study aimed to identify and describe the structures of the lower respiratory tract in red-foot tortoises, by computed tomography, radiography and gross anatomy in twelve red-foot tortoises (Chelonoidis carbonaria), adults and of both sexes. The lower respiratory tract in these animals comprised the larynx, trachea, bronchi and the lungs. The presence of epiglottic cartilage was not observed in the animals studied. CT allowed the observation of the intrapulmonary part of the bronchi, which was accompanied by large intrapulmonary blood vessels. The lungs presented a reticulated parenchyma, without lobulations. Each lung had a small chamber located near the cranial and caudal poles. These structures were identified in CT and 3D CT reconstructions and these could suggest that these chambers could be non-respiratory structures, and could be comparable to the air sacs of birds. This study establishes normal CT anatomy of the lower respiratory tract of the red-foot tortoise; and may be used as a reference in the assessment of respiratory disorders in this tortoise.
\end{abstract}

INDEX TERMS: Computed tomographic, lower respiratory tract, red-food tortoise, Chelonoids carbonaria, chelonians, respiratory system, radiography, anatomy, wildlife animals.

RESUMO.- [Anatomia radiológica e por tomografia computadorizada do trato respiratório inferior no jabuti-piranga (Chelonoidis carbonaria).] 0 diagnóstico de diversas afecções em quelônios é um desafio para a clínica veterinária, já que um exame físico detalhado com auscultação e palpação é difícil devido à presença da carapaça e do plastrão. A radiografia e a tomografia computadorizada (TC)

\footnotetext{
${ }^{1}$ Received on April 8, 2020.

Accepted for publication on June 22, 2020.

${ }^{2}$ Graduate Program in Wild Animals, Faculdade de Medicina Veterinária e Zootecnia (FMVZ), Universidade Estadual Paulista "Júlio de Mesquita Filho" (Unesp), Campus de Botucatu, Rua Prof. Doutor Walter Mauricio Correa s/n, Distrito de Rubião Junior, Botucatu, SP 18618-681, Brazil.

${ }^{3}$ Departamento de Reprodução Animal e Radiologia Veterinária, Faculdade de Medicina Veterinária e Zootecnia (FMVZ), Universidade Estadual
}

tem se mostrado benéficas para o diagnóstico, prognóstico e tratamento em muitas espécies animais. Assim, este estudo teve por objetivo identificar e descrever as estruturas do trato respiratório inferior no jabuti-piranga por meio da tomografia computadorizada, radiografia e anatomia em 12 jabutis-piranga (Chelonoidis carbonara), adultos e de ambos os sexos. Nos animais estudados, o trato respiratório

\footnotetext{
Paulista "Júlio de Mesquita Filho" (Unesp), Campus de Botucatu, Rua Prof. Doutor Walter Mauricio Correa s/n, Distrito de Rubião Junior, Botucatu, SP 18618-681, Brazil.

${ }^{4}$ Departmento de Anatomia, Instituto de Biociências, Universidade Estadual Paulista "Júlio de Mesquita Filho" (Unesp), Rua Prof. Dr. Antônio Celso Wagner Zanin 250, Distrito de Rubião Junior, Botucatu, SP 18618-689, Brazil. *Corresponding author: bruno.schimming@unesp.br
} 
inferior consistiu da laringe, traqueia, brônquios e os pulmões. A cartilagem epiglote não foi observada. A TC permitiu a observação da parte intrapulmonar dos brônquios, a qual estava acompanhada dos vasos sanguíneos intrapulmonares. 0s pulmões possuíam um parênquima reticulado, sem lobações. Cada pulmão tinha uma pequena câmara localizada junto aos pólos cranial e caudal. Estas estruturas foram identificadas na TC e na reconstrução 3D a partir da TC e poderiam ser estruturas não-respiratórias, podendo ser comparadas aos sacos aéreos das aves. Este estudo identificou a anatomia normal por meio da TC do trato respiratório inferior do jabuti-piranga, o que pode ser usado como referência para diagnóstico de desordens respiratórias nesta espécie.

TERMOS DE INDEXAÇÃO: Anatomia, radiologia, tomografia computadorizada, trato respiratório inferior, jabuti-piranga, Chelonoidis carbonaria, quelônios, sistema respiratório, radiografia e anatomia, animais selvagens.

\section{INTRODUCTION}

The red-foot tortoise (Chelonoidis carbonaria) belongs to the order Testudines, and to the family Testudinidae (SchimidtNielsen 1999, Vought et al. 2015). Although this chelonium is not listed as endangered species (Rhodin et al. 2017), there is anthropogenic pressure, caused by habitat degradation, introduction of invasive species, pollution, diseases, unsustainable use, traffic and climate change. Therefore, the red-foot tortoise has been created as a pet, although it is a target for illegal trade and smuggling (Nunes et al. 2010, Vought et al. 2015). However, the lack of knowledge about its creation has led to management errors, compromising health and animal welfare (Nunes et al. 2010). This corroborates the fact that red-foot tortoise is the chelonium most bred in captivity in Brazil and represents an expressive casuistry of attendance in the wildlife clinic (Matias et al. 2006).

The diagnosis of the various respiratory diseases such as pneumonia in chelonians is a challenge in the veterinary clinic. A detailed physical examination with auscultation and palpation is hard since the lungs and others organs are contained by the carapace and the plastron (Murray 1996, McArthur et al. 2004). Noninvasive diagnostic imaging techniques provide detailed information on all organic systems of animals, therefore, anatomical knowledge for disease recognition in radiographic examinations and interpretation of images in CT is essential (Pinto 2007). The diagnosis of respiratory alterations in chelonians is generally based on radiographic studies, but in radiographic examination of the respiratory system there is overlapping of structures such as plastron and carapace, which make difficult the accurate diagnosis of these alterations (Pinto 2007). According to Mackey et al. (2008), the CT showed lesions that the radiographic examination had not indicated, with rich details like size and shape of the different structures that constitute this pulmonary system, besides demonstrating the internal anatomy without overlapping of adjacent structures.

There are few studies on red-foot tortoise and other Brazilian chelonians, especially in relation to imaging studies and anatomical descriptions. To date, there is a description of the appendicular skeleton (Bortolini et al. 2012) and about the kidneys, recently performed by Dadalto (2017), and despite the prevalence of red-foot tortoise in Brazil, there are no data on the respiratory system of this species. Thus, the objective of this study was to describe the lower respiratory tract of red-foot tortoise, clinically healthy, raised in captivity, by imaging studies and gross anatomy, in order to provide subsidies to clinicians, surgeons and researchers, allowing them to obtain a better diagnosis of respiratory disorders in this group of tortoises.

\section{MATERIALS AND METHODS}

Animals. Twelve red-foot tortoises (Chelonoidis carbonaria) were used in this study (ten males and two females). Ten live animals were used for radiography and computed tomography, and two dead animals were used to anatomical studies. The cadavers of these animals were kept frozen until to perform dissections and anatomical sections. All the animals came from the "Centro de Medicina e Pesquisa em Animais Selvagens" (CEMPAS) of the "Faculdade de Medicina Veterinária e Zootecnia", Unesp, Botucatu, Brazil. The present study was carried out in accordance with ethical principles and with the approval of the Committee on Ethics in the Use of Animals (CEUA 998/2017).

Anesthetic management. For radiographic and tomographic examination, the animals were submitted to 24 hours of fasting prior to the anesthetic procedure. The tortoises were anaesthetized with a combination of ketamine hydrochloride $(0.5 \mathrm{mg} / \mathrm{kg})$ and propofol $(7 \mathrm{mg} / \mathrm{kg})$ injected intravenously in the dorsal cervical sinus. Anesthetic maintenance was used in smaller doses: ketamine hydrochloride $(0.2 \mathrm{mg} / \mathrm{kg})$ associated with propofol $(4 \mathrm{mg} / \mathrm{kg})$. Anesthesia monitoring was performed with the aid of cardiac Doppler. Cardiac and respiratory frequences were monitored throughout the procedure and anesthetic recovery.

Radiographic examination. All the imaging examinations of each animal were performed on the same day, aiming at reducing the possibility of deleterious effects related to general anesthesia. All analyzes were performed with spontaneous breathing. The animals were positioned in the ventral recumbency to avoid compression of the respiratory structures, on a rectangular foam cushion, with the neck and limbs extended. This avoided the overlapping of images and allowed the positioning similar to the normal anatomical position of this animal. Direct digital radiography equipment (DR-F; GE Health Care Unit, Brazil) was used to obtain the radiographic images of the respiratory system. For this, the incidence of dorsoventral, craniocaudal and lateral (with the animal placed on a plastron stand), with $100 \mathrm{~cm}$ film focus distance, were performed. The protocol of the radiographic technique was $60-68 \mathrm{kVp}$ and $4.0 \mathrm{mAs}$. After obtaining the radiographic images, they were transferred and later accessed in a PACS medical imaging system (Synapse, Fuji Medical System, Tokyo, Japan).

Computed tomography (CT). The equipment used to obtain the tomographic images was a single-slice helical tomograph of the third generation of the Shimadzu Mark, model SCT-7800 TC. Areas of interest for the study with continuous cuts of $1 \mathrm{~mm}$ and $2 \mathrm{~mm}$ in axial plane (perpendicular to the greater body of the body) were selected in the craniocaudal direction, using a protocol of $120 \mathrm{kVp}$ and 130 (pitch 2, 1-2mm increment and 1 second tube rotation time), $\mathrm{RF} 2$ reconstruction filter (soft tissue) and W: $320 \mathrm{~L}$ : 35 window for reconstruction, MPR and 3D. The filter RF5 PF9 (hard lung filter) and window W: 1800 L:-600 were also used for pulmonary evaluation. Due to the size of red-foot tortoise and limitations of the tomographic equipment, it was necessary to perform two tomographic cuts with different thicknesses to obtain good resolution images and the evaluation of the different structures of the respiratory system 
of these animals. The first cut was performed from the glottis to the beginning of the tracheal bifurcation with a thickness of $1 \mathrm{~mm}$. Subsequently, the second cut was performed, with a thickness of $2 \mathrm{~mm}$, which began at the tracheal bifurcation until the end of the carapace. The tomographic images were transferred to the software Voxar-3D ${ }^{\circledR}$ version 6.3 (Toshiba Medical Visualization; Edinburg, Scotland) for reconstruction of multiplanar images (MRP) in sagittal and dorsal planes and reconstruction in third dimension (3D) of the different structures. The two-dimensional tomographic images obtained and their three-dimensional reconstructions were evaluated in a PACS medical imaging system (Synapse, Fuji Medical System, Tokyo, Japan) for measurement of pulmonary volume, tracheal and extrapulmonary bronchi length, and tracheal caliber at the level of the first tracheal ring. The length of the trachea and right and left bronchi were measured.

Anatomical study. The dissection and anatomical description of the structures of the respiratory system were performed. The dissection was initiated by removal of the plastron, afterwards all anatomical structures were dissected and carefully removed from the body cavity. In order to establish a comparison with the different tomographic sections, cross-sectional anatomical sections were performed in slices of $4 \mathrm{~cm}$. All findings were documented and named according to the Nomina Anatomica Veterinaria (2017).

\section{RESULTS}

The larynx is the most rostral structure and is located caudal to the base of the tongue, in the caudomedial portion of the oral cavity leading directly to the trachea. This structure and its muscles are supported by the hyoid apparatus (Fig.1A-C). Laryngeal cartilages observed were arytenoids, cricoids, and thyroid cartilages (Fig.1C). No epiglottis cartilage was identified in this animal. On the CT scan and on the radiographs, the glottis was easily identified, since it was closed at the moment of the tomographic scan and the radiographic image was obtained (Fig.1A,D,E and 2F).

The trachea was observed caudally to the glottis, following the midline of the neck of the red-foot tortoise (Fig.1C, 3C, 4C, 5D). Subsequently, the trachea deflects towards the left side of the neck, where it runs until its ends (Fig.1D and 3A). This was formed by complete cartilaginous rings (Fig.1C and $3 \mathrm{~A}, \mathrm{C}$ ) and a left ventral position in relation to the esophagus (Fig.3A,C). The tracheal bifurcation occurs at the level of the fifth cervical vertebra, giving rise to the extrapulmonary parts of the left and right bronchi (Fig.3C, 4E, 5B, 2D). The trachea was easily identified in the radiographic projections (Fig.2D,F). The presence of air limited by the cartilaginous rings that constitute this tubular structure facilitated its visualization (Fig.1D,E, 3B,D, 2D,F). When the trachea was evaluated using
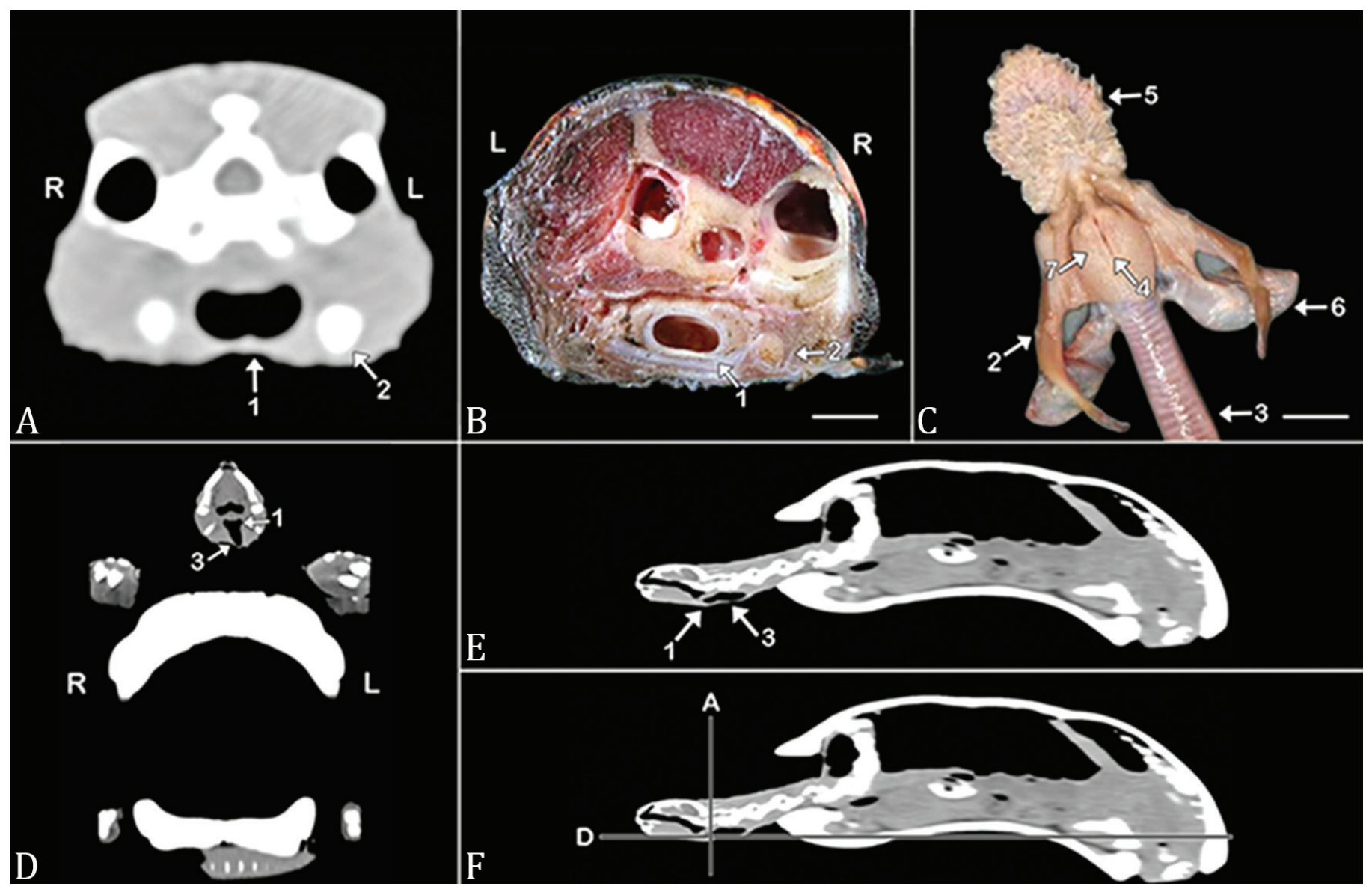

Fig.1. Tomographic and anatomical images of the glottis in the red-foot tortoise. (A) Computed tomography (CT) image, transverse plane (soft-tissue window). (B) Corresponding gross anatomical section in the level of glottis. Bar $=1 \mathrm{~cm}$. (C) Dorsal view of larynx. Bar $=1 \mathrm{~cm}$. (D) CT dorsal plane and (E) sagittal plane (soft-tissue window). (F) Reference to locate Figure A and D. Glottis (1), hyoid apparatus (2), trachea (3), opening of the glottis (4), tongue (5), thyroid cartilage wings (6), arytenoid cartilage (7), right side (R), and left side (L). 
3D virtual bronchoscopy, the tracheal rings were confirmed to be complete and the tracheal mucosa had a smooth surface (Fig.4C). Positioning of the trachea in relation to the esophagus was difficult to evaluate on CT, since the esophagus had no gaseous content in its lumen, which prevented its visualization in the tomographic sections (Fig.3B). However, the anatomical sections allowed to confirm topographically the position of the trachea in relation to the esophagus described previously. The average length of the trachea was $6.67 \pm 0.84 \mathrm{~cm}$, and its caliber, at the level of the first tracheal ring, had a mean of $0.60 \pm 0.11 \mathrm{~cm}$. The length of the extrapulmonary parts of the right bronchus was $4.55 \pm 0.91 \mathrm{~cm}$ and the left bronchus was $3.72 \pm 0.67 \mathrm{~cm}$, respectively.

The bronchi penetrated medially on the ventral surface of the lungs, originating the intrapulmonary part of the bronchi. The intrapulmonary bronchi were visualized in CT and anatomical sections, but were not identified in the anatomic dissection (Fig.6A,C). In tomographic evaluation, these intrapulmonary bronchi were accompanied by two blood vessels during their longitudinal course in the pulmonary parenchyma (Fig.6B,C,E). There were no branches of intrapulmonary bronchi, only chambers of different shapes and sizes, forming part of the pulmonary parenchyma (Fig.6A,C,E). The extra and intrapulmonary parts of the bronchi as well as the large pulmonary blood vessels were clearly identified in the 3D pulmonary reconstruction (Fig.7A-C).

The lungs were large structures with a reticulated aspect that extended dorsally, occupying a large part of the body cavity, from the region of the shoulder girdle to the cranial portion of the pelvic girdle (Fig.3A and 5D). The ventral surface of the lungs was separated from the other structures of the body cavity by a thin non-muscular membrane that completely recovered the lungs, there was difficulty in identifying this membrane in the anatomical dissection because of its fragility (Fig.5A,D). There is a close relationship of the dorsal surface of the lung with a large part of the spine, rib heads (caput costae) and dermal bone plates that form the dorsal part of the carapace (Fig.5C).

No pulmonary lobes were identified in the red-foot tortoise (Fig.5C,D). The parenchyma was described as strongly reticulated (Fig.5A and 6A). Pulmonary volume was calculated by means of $3 \mathrm{D}$, being $69.04 \pm 15,55 \mathrm{~cm}^{3}$ on average. Hyperdensal areas were observed on the ventral surface of the lung, related to the intestinal loops (Fig.7C,E). Each lung had a small chamber located dorsomedially at the cranial and caudal poles, without the presence of calibrous blood vessels close to them. These structures were clearly identified in the 3D reconstruction (Fig.7A,C,F), as well as in all tomographic sections (Fig.8A-F) and in the Ld radiographic projection, however, they were not identified in the anatomical dissection. Radiographically, the lung was observed to be a radiolucent structure. In the craniocaudal and right lateral projections, it was possible to identify the close pulmonary relation with the carapace and with most of the organs of the body cavity (Fig.2E,F).
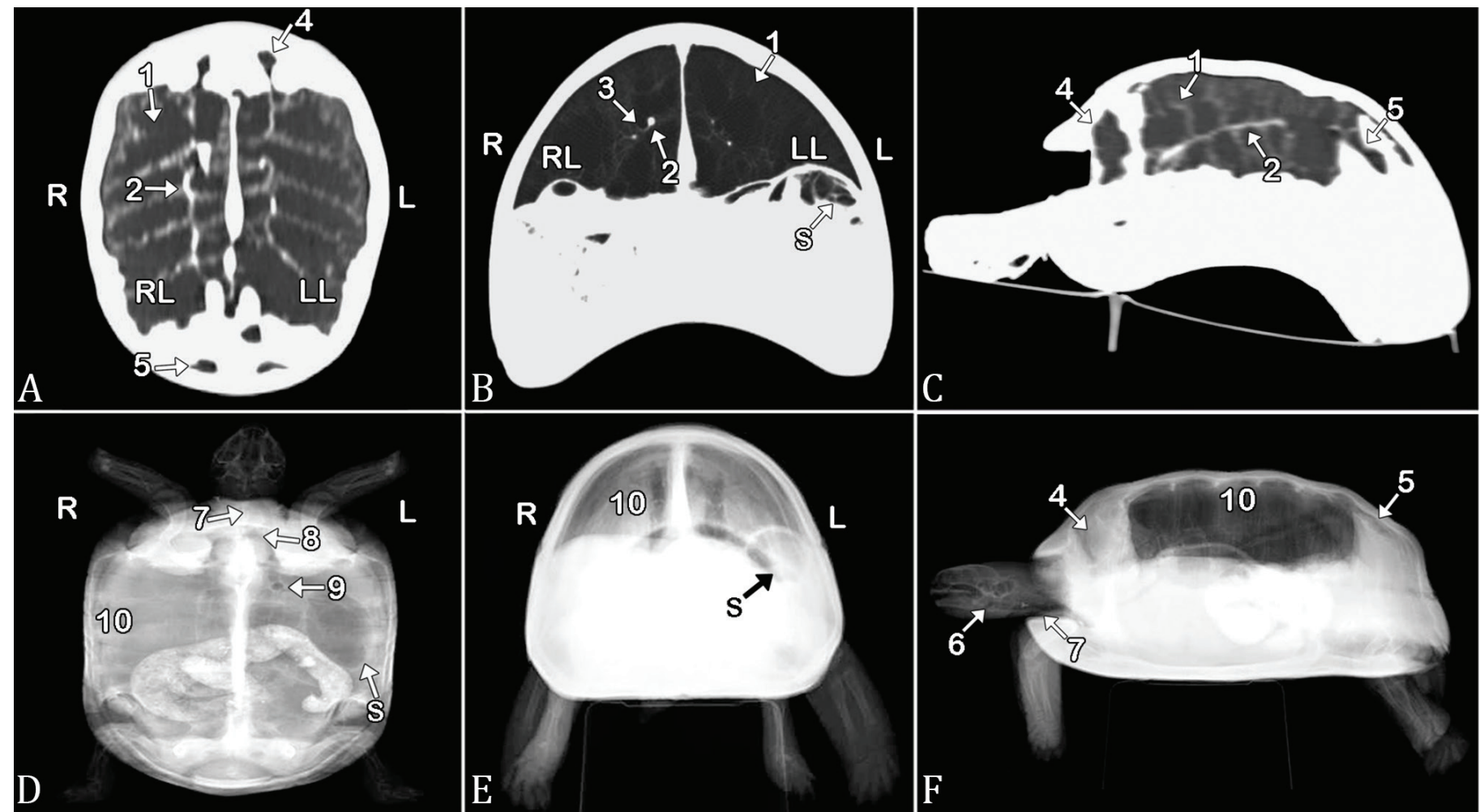

Fig.2. Tomographic and radiographic images of the lungs in the red-foot tortoise. (A, B, C) Tomographic sections: dorsal, transverse and sagittal planes, respectively (pulmonary window). Radiographic imagens in (D) dorsoventral, (E) craniocaudal and (F) right lateral projections. Pulmonary chambers (1), pulmonary blood vessel (2), intrapulmonary part of the right bronchus (3), cranial lung chamber (4), caudal pulmonary chamber (5), glottis (6), trachea (7), carina (8), entry of the left bronchus into the lung (9), lungs with overlapping structures (10), stomach (S), right side (R), and left side (L). 

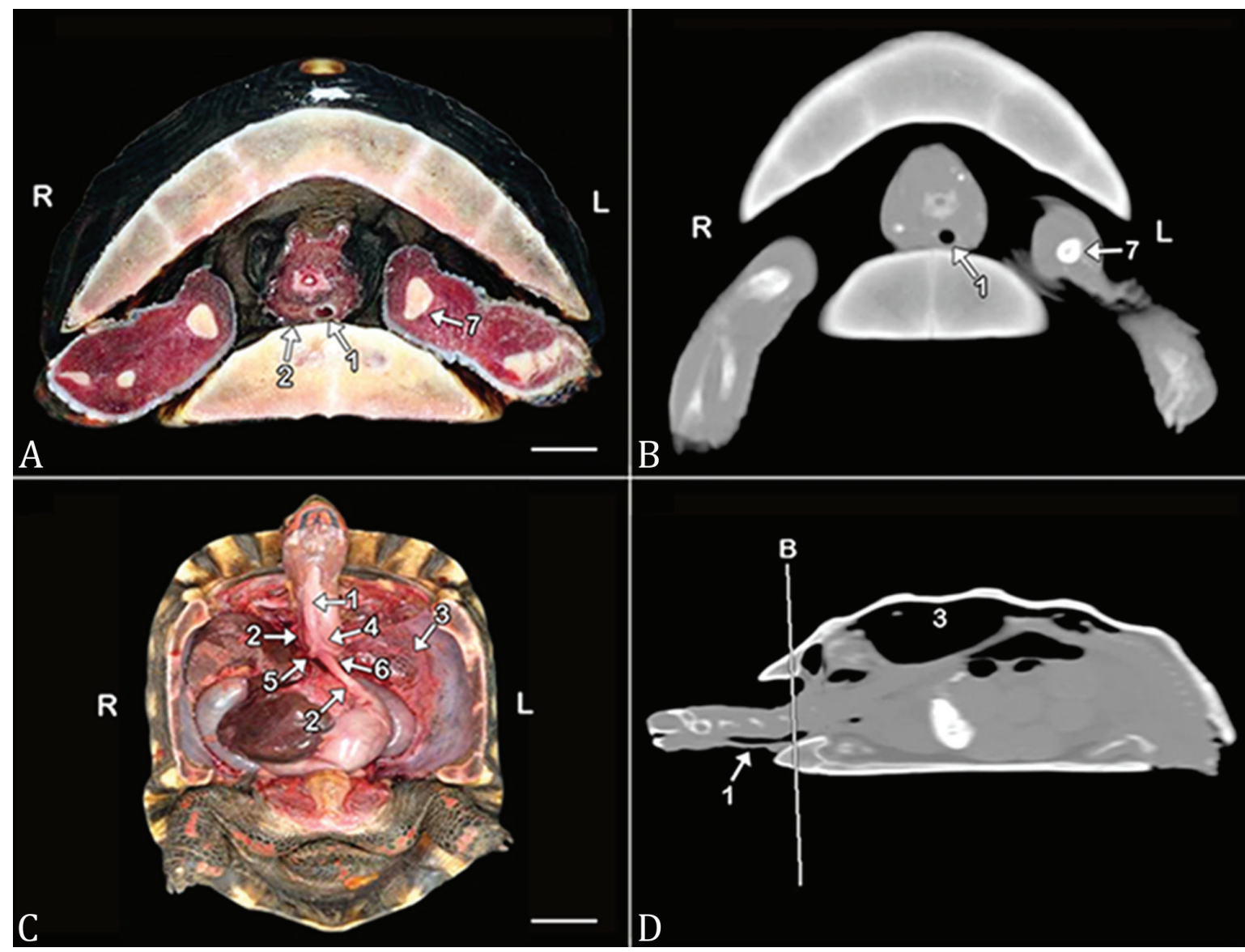

Fig.3. Anatomical and tomographic images of the trachea in the red-foot tortoise. (A) Corresponding gross anatomical section. Bar $=9 \mathrm{~cm}$. (B) Computed tomography (CT) image transverse plane (bone window). (C) Ventral view of lower respiratory tract. Bar $=9 \mathrm{~cm}$. (D) CT sagittal plane (bone window). Reference to locate Figure B. Trachea (1), esophagus (2), lung (3), tracheal bifurcation (4), extrapulmonary part of the right bronchus (5), extrapulmonary part of the left bronchus (6), humerus (7), right side (R), and left side (L).

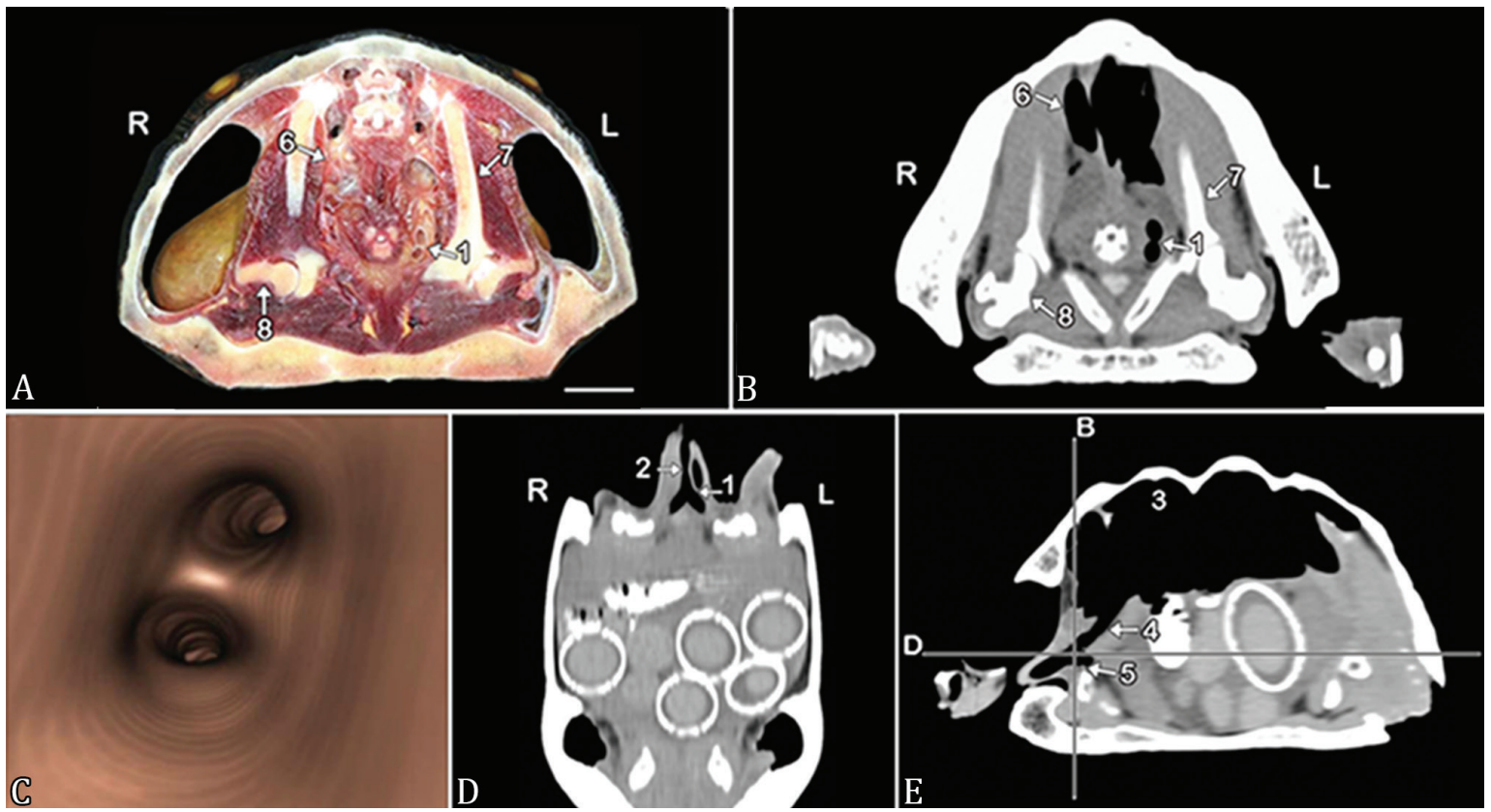

Fig.4. Anatomical and tomographic images of the tracheal bifurcation in the red-foot tortoise. (A) Corresponding gross anatomical section. Bar $=7 \mathrm{~cm}$. (B) Computed tomography (CT) transverse plane (soft-tissue window). (C) Virtual bronchoscopy image. (D) CT dorsal plane (soft-tissue window). (E) Reference to locate the Figure B and D. Tracheal bifurcation (1), trachea (2) left lung (3), extrapulmonary part of the left bronchus (4), extrapulmonary part of the right bronchus (5), cranial pulmonary chamber (6), scapula (7), humerus (8), right side (R), and left side (L). 


\section{DISCUSSION AND CONCLUSION}

In the chelonians, the knowledge of anatomy of the lower respiratory tract is of great clinical importance, since inflammatory exudates particularly those associated with infectious diseases tend to accumulate in the lungs, due to the fact that the respiratory tract has a primitive mucociliary apparatus, and thus, chelonians could not effectively expel exudates from their lungs (Murray 1996). According to Tracchia (2018), is pivotal to know the anatomy and physiology of the chelonians respiratory tract because the absence of a real diaphragm, the absence of a bronchial ciliated epithelium, the opening of the bronchi in the dorsal aspect of the lungs, and their trabecular appearance cause the secretions produced by pneumonia and it tends to accumulate in the lungs and air sacs since they are scarcely eliminated by the airways. So, this study used CT, radiography and gross anatomy to describe the constituents of the lower respiratory system of red-foot tortoise (Chelonoidis carbonaria).
The lower respiratory tract in the red-foot tortoise is composed of larynx, trachea, right and left bronchi and lungs. These results were in agreement with those reported for the sea turtle (Caretta caretta) and Egyptian tortoise (Testudo kleinmanni) (Valente et al. 2007, Saber \& Kamal 2010).

Mayor (2017) described the presence of the epiglottic cartilage in Chelonoidis denticulata. A different result was found in this study, in which the presence of this cartilage was not observed in the larynx of $C$. carbonaria, although the two species of tortoises belong to the same Genus. The absence of the epiglottis has been reported in chelonians (O'Malley 2005). In the absence of the epiglottis, the closed glottis is opened by the dilator of glottis muscle (O'Malley 2005, Devoe 2010).

Several previous studies (Christopher \& Hernandez-Divers 2003, O'Malley 2005, Valente et al. 2007, Zehtabvar et al. 2014) have described that trachea is composed of complete cartilaginous rings, following the pattern described herein
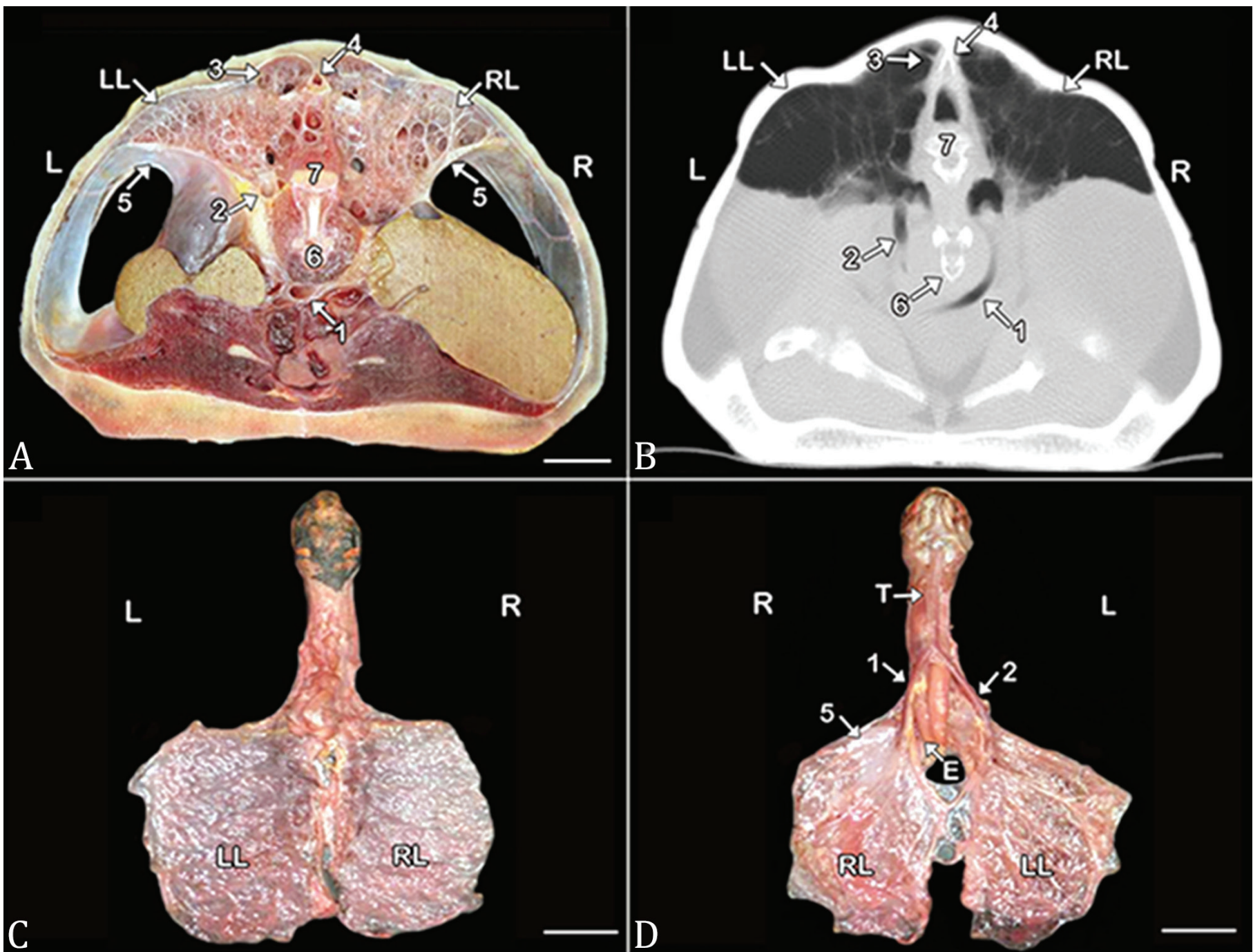

Fig.5. Anatomical and tomographic images of pulmonary bronchi in the red-foot tortoise. (A) Corresponding gross anatomical section. Bar $=7 \mathrm{~cm}$. (B) Computed tomography (CT) transverse plane (pulmonary window). (C) Dorsal view of the lungs. Bar $=4 \mathrm{~cm}$. (D) Ventral view of the respiratory system. Bar $=4 \mathrm{~cm}$. Extrapulmonary part of the right bronchus (1), extrapulmonary part of the left bronchus (2), pulmonary chambers (3), eighth cervical vertebra (4), pulmonary septum (5), sixth cervical vertebra (6), seventh cervical vertebra (7), esophagus (E), trachea (T), right lung (RL), left lung (LL), right side (R), and left side (L). 

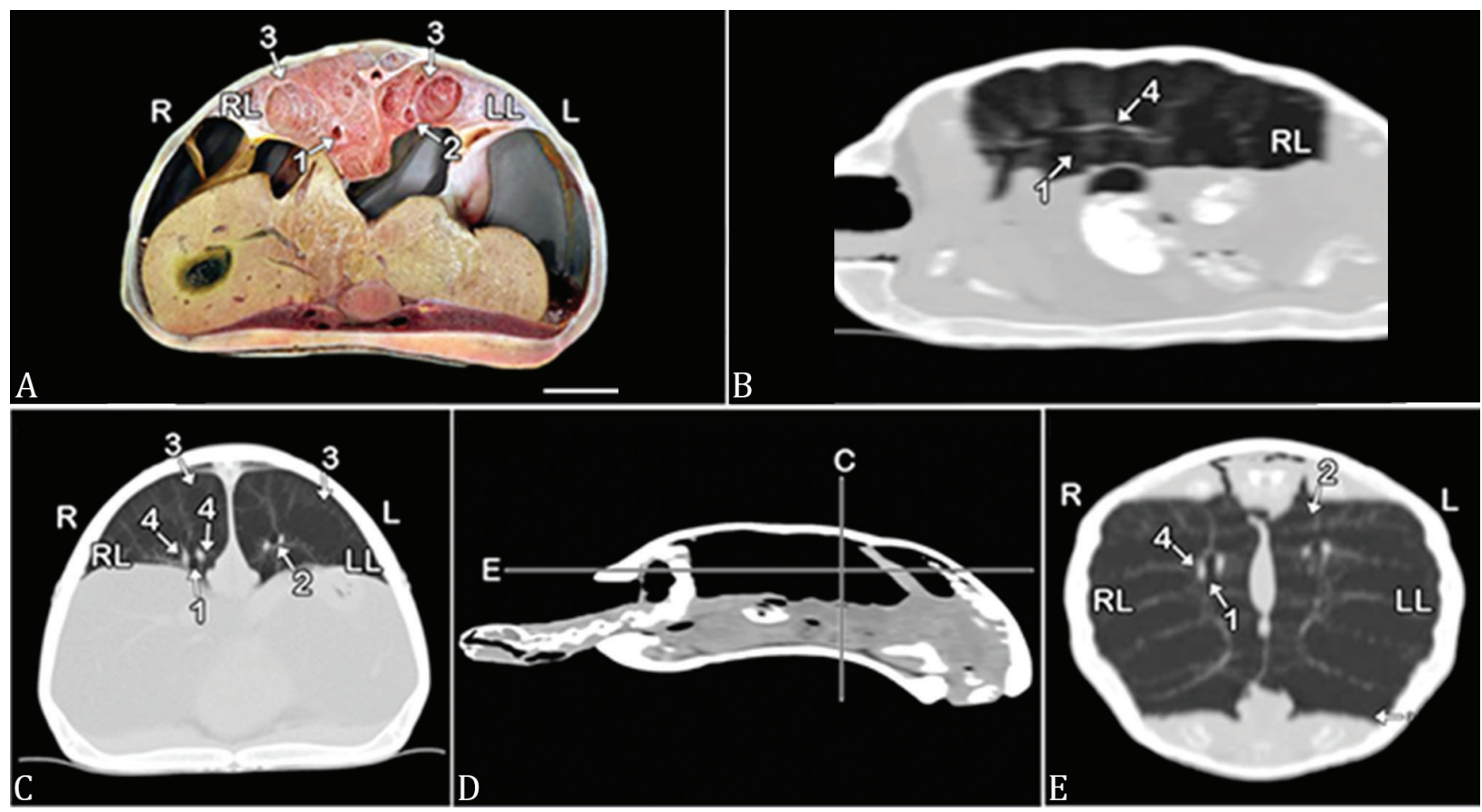

Fig.6. Anatomical and tomographic images of the lungs in the Chelonoidis carbonaria . $($ A) Corresponding gross anatomical section. Bar $=$ $7 \mathrm{~cm}$. (B) Computed tomography (CT) sagittal plane and (C) transverse plane (pulmonary window). (D) Reference to locate Figure C and E. (E) CT dorsal plane. Intrapulmonary part of the right bronchus (1), left bronchus intrapulmonary part (2), pulmonary chambers (3), pulmonary blood vessels (4), right lung (RL), left lung (LL), right side (R), and left side (L).
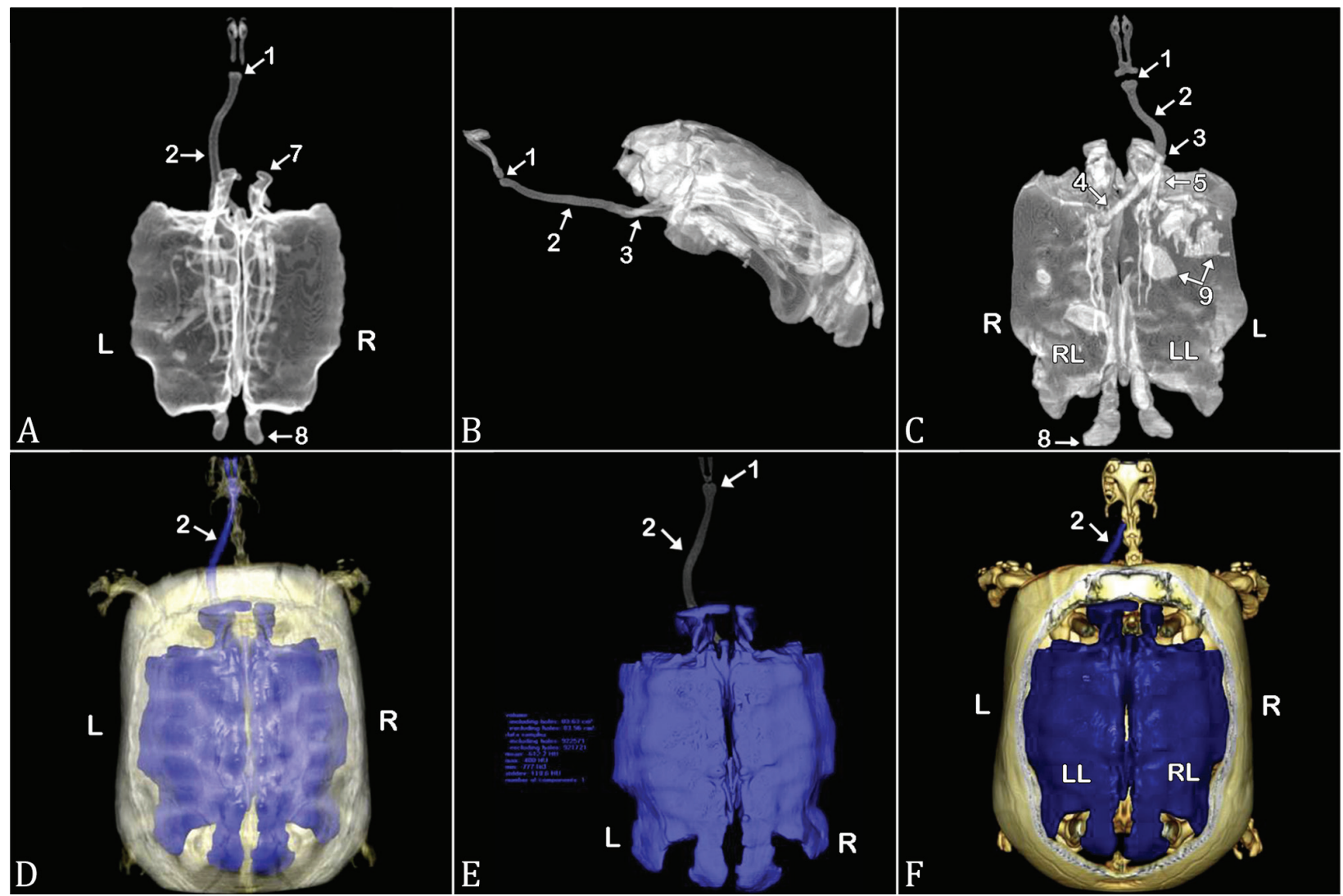

Fig.7. (A) Dorsal, (B) lateral, and (C) ventral views of 3D CT reconstructions of the lower respiratory tract in the red-foot tortoise. (D, F) Position of the respiratory tract in relation to the skeleton. (E) Representation of calculation of the pulmonary volume. Glottis (1), trachea (2), Carina (3), extrapulmonary part of right bronchus (4), extrapulmonary part of the left bronchus (5), pulmonary blood vessels (6), cranial lung chamber (7), caudal pulmonary chamber (8), remnants of intestinal loops with gaseous contents (9), right lung (RL), left lung (LL), right side (R), and left side (L). 
for the red-foote tortoise. The trachea presents variable positions in the different species of chelonians. In sea turtle, it is positioned ventrally and to the right of the esophagus (Valente et al. 2007), whereas the trachea of the red-foot tortoise is ventrally and the left esophagus, similar to that observed in European pond turtle (Emys orbicularis) (Zehtabvar et al. 2014).

Regarding the length of the trachea, this was in agreement that described for European pond turtle (Zehtabvar et al. 2014), although they were species of different habits, morphological characteristics and families. In contrast, the length of the extrapulmonary part of the bronchi and the difference in length between the right and left bronchi observed in this study were considerably higher than that reported for that tortoise. Valente et al. (2007) with the use of virtual 3D bronchoscopy have described that the tracheal mucosa has a smooth surface, as observed in the red-foot tortoise. The position of the carina found in the present study is considerably more cranial than in sea turtles, where the trachea branches after the first dorsal vertebra (Valente et al. 2007) and in the European pond turtle, where it forks between the eighth and ninth cervical vertebra. However, in Egyptian tortoise, the carina was identified more cranially, at the level of the second to fourth cervical vertebra (Saber \& Kamal 2010), although it is also a terrestrial chelonius as the species of this study. The difference in the position of the carina seems to be related to the morphofunctional characteristics of the neck observed in the different groups of the Testudines.

Perry (1983) stated that the intrapulmonary bronchus of the chelonians does not have branching. In contrast, Kiefer \& Pees (2011) reported that it has its trajectory in the pulmonary tissue as a central airway and branches into smaller terminal bronchioles that reach the pulmonary chambers, in agreement with that observed in red-foot tortoise. The blood vessels that accompany the intrapulmonary part of the bronchus were identified histologically, as pulmonary artery and vein, located, respectively, dorsally and ventrally to the bronchus (Valente et al. 2007). In the present study it was not possible to observe this differentiation between these blood vessels.

The pulmonary anatomy of the red-foot tortoise is comparable to that found in other species of Testudines, but with differences in the relative size of the lungs. Terrestrial chelonians appear to have much more pulmonary volume than sea turtles (Valente et al. 2007). In CT at the base of the heart, in a sea turtle, the lungs occupied only the dorsal third of the body cavity (Valente et al.2007), whereas in terrestrial chelonians, the lungs occupy about two-thirds of body cavity (Wilkinson et al. 2004), as seen in the specie of this study.

The red-foot tortoise have lungs morphologically characterized as large multi-chamber structure, with many septa and rich in reticulated parenchyma, similar to that reported for other terrestrial Testudines (Christopher \& Hernandez-Divers 2003, Duncker 2004). Schachner et al. (2017) claimed that traditionally the morphology of the turtle lungs is multichambered. One of the most important clinical contributions of tomography examination is to describe the relationship of the respiratory system with other organs. Studies using CT in sea turtles (Valente et al. 2007) and terrestrial chelonians (Saber \& Kamal 2010) reported that the lungs were not lobed and the pulmonary parenchyma was heavily reticulated. These findings were in agreement with that observed in C. carbonaria.
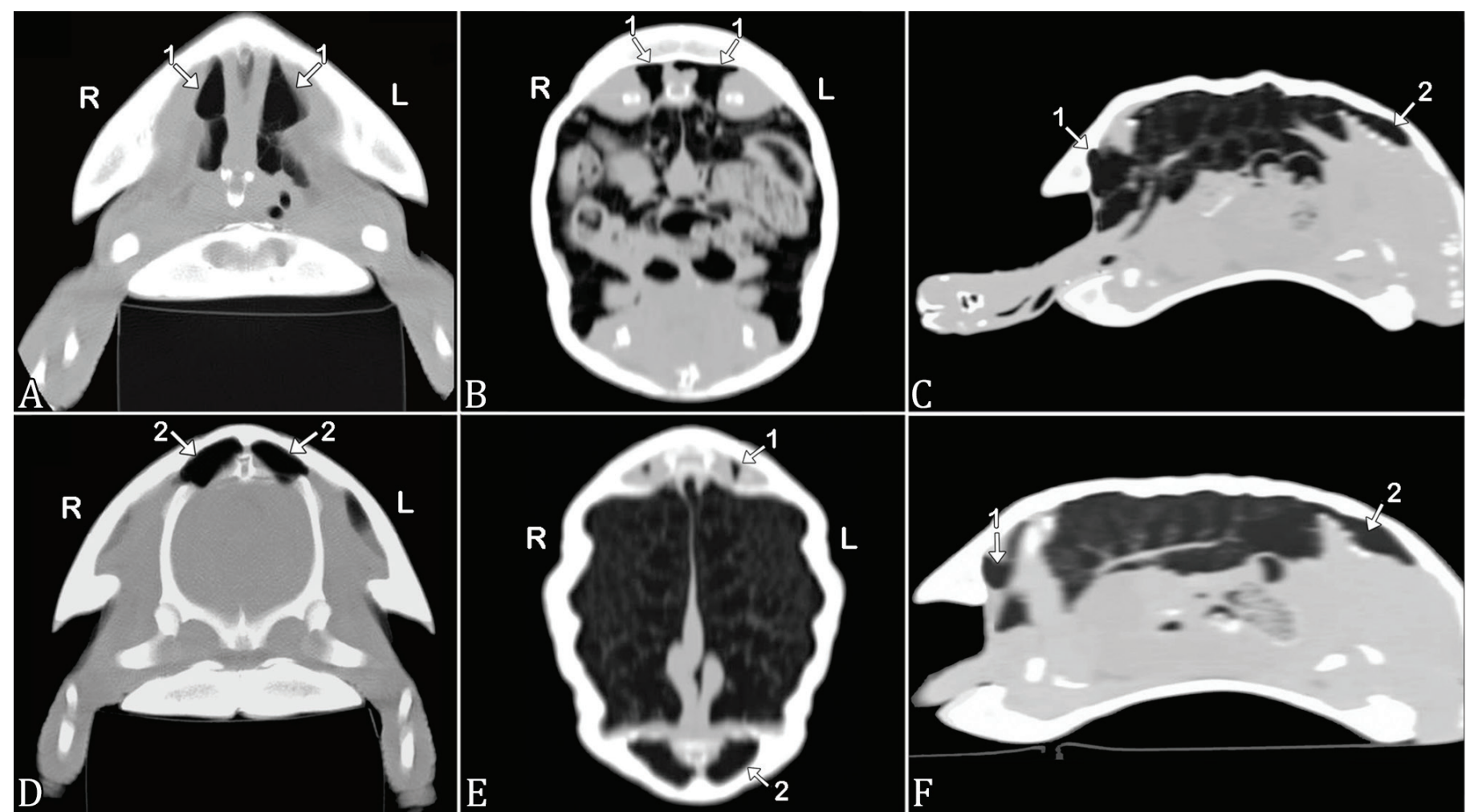

Fig.8. Tomograhic images of the cranial and caudal chambers of the lungs in the red-foot tortoise. (A,D) CT transverse, (B,E) dorsal, and (C,F) sagittal planes (soft-tissue window). Cranial lung chamber (1), caudal lung chamber (2), right side (R), and left side (L). 
In the present study, it was observed that the lungs were separated from the other structures of the body cavity, by a thin non-muscular membrane. Some authors such as Perry (1983) and Schumacher (2011) reported the existence of this structure, called the "post-pulmonary septum" or "pleural membrane", which may cover all or part of the lungs depending on the species of chelonians. This structure can influence ventilatory mechanics (Schumacher 2011). This membrane was not described in some studies performed on chelonians (Valente et al. 2007, Saber \& Kamal 2010, Zehtabvar et al. 2014). It was not possible to visualize this post-pulmonary septum in the radiographic and tomographic images performed in the red-foot tortoise. It is suggested that this was due to the low thickness of this membrane or due to the limitation of the CT employed here.

Small pulmonary chambers were identified in the tomographic sections and $3 \mathrm{D}$ reconstructions described in this study. Such chambers were not identified in the anatomical study, probably because the lungs were not inflated. We suggest that these pulmonary dilatations could be non-respiratory structures, with little vascularity, comparable to the air sacs of birds, based on the reports of O'Malley (2005) and Devoe (2010), who affirmed the presence of this type of structures in the lungs in others species of reptiles such as snakes and lizards. This finding suggesting performing other methods of investigation to address this question.

Craniocaudal and lateral radiographic projections are commonly used to detect pulmonary diseases in routine care in Testudines (Hernandez-Divers 2006). However, when associated with carapace fracture, the local inflammatory response and the overlap of the bone fragment usually prevent an accurate evaluation of the pulmonary parenchyma. Based on the results observed in the present study, the radiography did not allow a more detailed and reliable evaluation of all respiratory structures in red-foot tortoise. CT and 3D reconstructions plays an important role in the diagnosis of a wide several diseases in a variety of animals (Garland et al. 2002). Valente et al. (2007) postulated to the use of CT for the evaluation of the respiratory system of sea turtles and affirm that it provides accurate information about the lungs and airways, in agreement with that observed in this study in red-foot tortoise.

The comparison with the anatomical sections was indispensable in our study for the recognition of anatomical structures in CT images. Some soft tissue celomatous structures, such as the esophagus, could not be identified in tomographic images because of their small size, the lack of contrast between them and surrounding tissues, and the resolution of the conventional CT employed here. The CT avoids overlapping structures, both skeletal and soft tissue, observed on radiographs. The slow respiratory rate of these animals associated with air-lung contrast provided a detailed and high-quality visualization of the lungs and airways. The lower respiratory tract in the redfoot tortoise was similar to that reported to other Testudines and based on the findings of this study, we recommend that CT could be the better technique for a good diagnostic in a large variety of respiratory problems in Testudines.

\footnotetext{
Acknowledgments.- The authors would like to thanks "Centro de Medicina e Pesquisa em Animais Selvagens" (CEMPAS) of the "Faculdade de Medicina Veterinária e Zootecnia", Unesp, for providing the animals.
}

Conflict of interest statement.- The authors have no conflict of interest.

\section{REFERENCES}

Bortolini Z., Lehmkuhl R.C., Ozeki L.M., Tranquilim M.V., Sesoko N.F., Teixeira C.R. \& Vulcano L.C. 2012. Association of 3D reconstruction and conventional radiography for the description of the appendicular skeleton of Chelonoidis carbonaria (Spix, 1824). Anat. Histol. Embryol. 41(6):445-452. <http:// dx.doi.org/10.1111/j.1439-0264.2012.01155.x>

Christopher S.H. \& Hernandez-Divers S. 2003. Practical gross pathology of reptiles. Semin. Avian Exot. Pet Med. 12(2):71-80. <https://dx.doi. org/10.1053/saep.2003.127883>

Dadalto C.R. 2017. Estudo tomográfico, ultrassonográfico e dopplerfluxométrico renal de jabutis-piranga (Chelonoidis carbonarius, Spix, 1824). Master's Thesis, Universidade Estadual Paulista, Botucatu. 79p.

Devoe R. 2010. Anatomia e fisiologia de anfíbios e répteis, p.455-478. In: Colville T. \& Bassert J.M. (Eds), Anatomia e Fisiologia Clínica para Medicina Veterinária. Elsevier Saunders, Rio de Janeiro.

Duncker H.R. 2004. Vertebrate lungs: structure, topography and mechanics. A comparative perpective of the progressive integration of respiratory system, locomotor apparatus and ontogenetic development. Resp. Physiol. Neurobi. 144(2/3):111-124. <https://dx.doi.org/10.1016/j.resp.2004.07.020>

Garland M.R., Lawler L.P., Whitaker B.R., Walker I.D.F., Corl F.M. \& Fishman E.K. 2002. Modern CT applications in veterinary medicine. Radiographics 22(1):55-62.<https://dx.doi.org/10.1148/radiographics.22.1.g02ja1155> $<$ PMid:11796898>

Hernandez-Divers S.J. 2006. Reptile radiology: techniques, tips and pathology. Proceedings of the North American Veterinary Conference, Orlando, Florida, p.1626-1630.

Kiefer I. \& Pees M. 2011. Tomografia computadorizada en reptiles, p.360363. In: Krautwald-Junghanns M.E., Pees M., Reese S. \& Tully T. (Eds), Diagnóstico por Imagen en Animales Exóticos: aves, pequeños mamíferos y reptiles. Multimédica, Barcelona.

Mackey E.B., Hernadez-Divers S.J., Holland M. \& Frank P. 2008. Clinical technique: Application of computed tomography in zoological medicine. J. Exot. Pet Med.17(3):198-209. <https://dx.doi.org/10.1053/j.jepm.2008.05.007>

Matias C.A.R., Romão M.A.P., Tortelly R. \& Bruno S.F. 2006. Aspectos fisiopatológicos da retenção de ovos em jabuti-piranga (Chelonoidis carbonaria Spix, 1824). Ciência Rural 36(5):1494-1500. <http://dx.doi. org/10.1590/S0103-84782006000500023>

Mayor P. 2017. Atlas de Anatomía de Especies Silvestres de La Amazonía Peruana. Avaliable at <http://atlasanatomiaamazonia.uab.cat> Acessed on Dec. 14, 2017.

McArthur S., Wilkinson R. \& Meyer J. 2004. Medicine and Surgery of Tortoises and Turtles. Blackwell, Oxford.

Murray M.J. 1996. Pneumonia and normal respiratory function, p.386-405. In: Mader D.R. (Ed.), Reptile Medicine and Surgery. W.B. Saunders, Philadelphia.

Nomina Anatomica Veterinaria 2017. Nomina Anatomica Veterinaria. 6th ed. International Committee on Veterinary Gross Anatomical Nomenclature, World Association of Veterinary Anatomists, Hannover.

Nunes O.C., Oliveira E.D., Laborda S.S., Hohlenwerger J.C., Moaes Neto M. \& Franke C.R. 2010. Isolamento e identificação de Salmonella sp. de jabutispiranga (Chelonoidis carbonaria) oriundos do tráfico de animais silvestres. Ciênc. Animal Bras. 11(1):168-173. <https://dx.doi.org/10.5216/cab. v11i1.4646>

0’Malley B. 2005. Clinical Anatomy and Physiology of Exotic Species. Elsevier Saunders, Saint Louis, p.41-56.

Perry S.F. 1983. Reptilian lungs. functional anatomy and evolution. Adv. Anat. Embryol. Cell Biol. 79:1-81. <PMid:6869074>

Pinto A.C.B.C.F. 2007. Radiologia, p.896-919. In: Cubas Z.S., Silva J.C.R. \& Catão-Diaz J.L. (Eds), Tratado de Animais Selvagens: medicina veterinária. Roca, São Paulo. 
Rhodin A.G.J., Iverson J.B., Bour R., Fritz U., Georges A., Shaffer H.B. \& Van Dijk P.P. 2017. Turtles of the world: Annotated checklist and atlas of taxonomy, synonymy, distribution, and conservation status. Avaliable at <http://www.iucn-tftsg.org/checklist/> Acessed on Jan. 16, 2017.

Saber A.S. \& Kamal B.M. 2010. Computed tomography and 3D reconstruction of the respiratory organs of the Egyptian tortoise (Testudo kleinmanni). J. Vet. Anat. 3(3):1-15. <http://dx.doi.org/10.21608/jva.2010.44902>

Schachner E.R., Sedlmayr J.C., Schott R., Lyson T.R., Sanders R.K. \& Lambertz M. 2017. Pulmonary anatomy and a case of unilateral aplasia in a common snapping turtle (Chelydra serpentine): developmental perspectives on cryptodiran lungs. J. Anat. 231(6):835-848. <dx.https://doi.org/10.1111/ joa.12722><PMid:29063595>

Schimidt-Nielsen K. 1999. Fisiologia Animal. Adaptação ao Meio Ambiente. Santos Livraria, São Paulo, p.101.

Schumacher J. 2011. Respiratory medicine of reptiles. Vet. Clin. N. Am., Exot Anim. Pract.1(2):207-224. <https://dx.doi.org/10.1016/j.cvex.2011.03.010> <PMid:21601811>

Tracchia A.C. 2018. Medicina en Quelonios y Otros Reptiles. Vazquez Mazzini Editores, Buenos Aires, p.239-243.
Valente A.L.S., Cuenca R., Zamora M.A. \& Parga M.L. 2007. Computed tomography of the vertebral column and coelomic structures in the normal loggerhead sea turtle (Caretta caretta). Vet. J. 174(2):362-370. <https://dx.doi.org/10.1016/j.tvjl.2006.08.018><PMid:17084649>

Vought R.C., Fagundes C.K., Bataus Y.S.L., Balestra R.A.M., Batista F.R.W., Uhlig V.M., Silveira A.L., Bager A., Batistella A.M., Souza F.L., Drummond G.M., Reis I.K., Bernhard R., Mendonça S.H.S.T. \& Luz V.L.F. 2015. Avaliação do risco de extinção de Chelonoidis carbonaria (Spix, 1824) no Brasil. Processo de avaliação do risco de extinção da fauna brasileira. ICMBIO, Brasília. Available at <http://www.icmbio.gov.br/portal/biodiversidade/faunabrasileira/estado-de-conservacao/7399-repteis-chelonoidis-carbonariajabuti-piranga.html> Acessed on Feb. 02, 2018.

Wilkinson R., Hernandez-Divers S., Lafortune M., Calvert I., Gumpen-Berger M. \& McArthur M. 2004. Diagnostic imaging, p.187-238. In: McArthur S., Wilkinson R. \& Jean M. (Eds), Medicine and Surgery of Tortoises and Turtles. Blackwell Publishing, Victoria.

Zehtabvar O., Tootian Z., Vajhi A., Shojaei B., Rostami A., Davudypoor S., Sadeghinezhad J., Ghaffari H. \& Memarian I. 2014. Computed tomography anatomy and topography of the lower respiratory system of the European pond turtle (Emys orbicularis). Iranian J. Vet. Surg. 9(2):9-15. 